Japan. J. Med. Sci. Biol., 27, 309-314, 1974

\title{
A CONSIDERATION TO IMMUNE DOSES OF STAPHYLOCOCCAL ENTEROTOXIN B TO RABBITS
}

\author{
KUNIHIRO SHINAGAWA, MASANORI ISHIBASHI, HIROYUKI YAMAMOTO, \\ NobUhaRU KUNITA, KAZUO HISA* AND GenJi SAKAGUCHI* \\ Osaka Prefectural Institute of Public Health, Nakamichi, Higashinari-ku, \\ Osaka-shi, Osaka 537 and ${ }^{*}$ College of Agriculture, University \\ of Osaka Prefecture, Sakai-shi, Osaka 591, Japan
}

(Received: July 4, 1974)

\begin{abstract}
SUMMARY : Immune doses of staphylococcal enterotoxin B to rabbits were studied by comparing the efficiency of various immunization schedules. It was experienced that even two subcutaneous injections each with such a small dose as $10 \mu \mathrm{g}$ of enterotoxin B, the primary one with Freund's complete adjuvant and a booster one without adjuvant, could stimulate a rabbit to develop the antibody to a satisfactorily high titer determined by agar gel diffusion and passive hemagglutination.
\end{abstract}

\section{INTRODUCTION}

Much progress has been made in studies on staphylococcal enterotoxins since highly specific in vitro immunological methods became available for quantitative determination of the toxin (Bergdoll, Borja and Avena, 1965; Hall et al., 1965; Surgalla et al., 1952). For any method of in vitro immunological determination, it is required to use a potent type-specific antitoxin prepared with purified enterotoxin of each type. To obtain such antitoxin, purified enterotoxin in an amount of milligrams or even tens of milligrams is injected in many doses into a suitable animal, usually the rabbit, through various routes at various intervals (Bergdoll et al., 1965; Casman and Bennett, 1964; Casman et at., 1967; Genigeorgis et al., 1971; Hilker et al., 1968; Kato et al., 1966; Read et al., 1965; Silverman, 1963); Since large-scale purification of staphylococcal enterotoxin requires laborious work, we examined efficiencies of immunization of the rabbit with smaller quantities of purified enterotoxin B. The immunization procedures reported by Casman et al. (1967) for staphylococcal enterotoxin D, by Genigeorgis, Sakaguchi and Rieman (1973) for Clostridium perfringens type A enterotoxin, and by Sakaguchi and Sakaguchi (1973) for Clostridium botulinum type E progenitor toxin were compared. We found that a total of only $20 \mu \mathrm{g}$ of enterotoxin $\mathrm{B}$ was enough to stimulate a rabbit to produce anti-enterotoxin B to a satisfactorily high level.

品川邦沉・石橋正憲・山本博之 - 国田信治 (大阪府立公衆衛生研究所 大阪市東成区中道 1-3-69) 日佐和夫・阪口玄二（大阪府立大学農学部 堺市百舌鳥梅町 4 丁目 804) 


\section{MATERIALS AND METHODS}

Enterotoxin: Purified enterotoxin B, purchased from Makor Chemicals, Jerusalem, Israel was used for immunizing the rabbit, for sensitizing sheep red blood cells to be used for passive hemagglutination (PHA), and as reference toxins for the immunological tests. A crude preparation of enterotoxin B provided by Dr. M. S. Bergdoll, Food Research Institute, University of Wisconsin, Madison, Wisconsin was also used for references in immunological tests.

Reference anti-enterotoxin B: Rabbit anti-enterotoxin B (agar gel diffusion titer 1:64) was provided also by Dr. M. S. Bergdoll.

Immunization of rabbits: Male albino rabbits, weighing $2.5-3.0 \mathrm{~kg}$, were used. None of them possessed anti-enterotoxin B to a detectable level prior to immunization. For primary immunization, equal volumes of an enterotoxin solution in saline at an appropriate concentration and Freund's complete adjuvant (Difco Lab. Inc., Detroit, Michigan) were mixed thoroughly by use of two syringes connected with a hypodermic needle. No adjuvant was used for booster injections. All injections were made subcutaneously on the upper part of the back of each rabbit with 1-ml doses containing indicated quantities of enterotoxin. The following time schedules were adopted:

A) Initially with $0.4,2.0,4.0,10,20,50,100$ and $160-\mu$ g enterotoxin with adjuvant at one-week intervals; after a 2 -week rest, 250, 540, and 1,000- $\mu$ g doses without adjuvant every other weeks (Casman et al., 1967).

B) Initially with $0.25,2.5,10,25$, and $25 \mu$ g with adjuvant at 3-day intervals; after a 2-month rest, additional $145 \mu \mathrm{g}$ without adjuvant (Genigeorgis et al., 1973).

C) Three successive injections each with $100 \mu \mathrm{g}$ at 3-day intervals with adjuvant; after the titer has reached plateau, or 8 weeks after the first injection, a single booster injection with $100 \mu \mathrm{g}$ of enterotoxin without adjuvant.

D) A single injection with $300 \mu \mathrm{g}$ with adjuvant; after a 7 -week interval, a booster injection with the same dose of the toxin without adjuvant.

E) A single injection with $10 \mu \mathrm{g}$ with adjuvant; after a 6 -week interval, a booster injection with the same dose without adjuvant.

The schedules (C), (D), and (E) were adopted from the experience with type $\mathrm{E}$ botulinum toxin (Sakaguchi and Sakaguchi, 1973). Blood samples were taken every week from each animal to be titrated for passive hemagglutination and agar gel diffusion titers.

Passive hemagglutination (PHA) test: The same procedures as those used for titration of type E botulinum antitoxin (Sakaguchi and Sakaguchi, 1973) were applied. Formalinized sheep red blood cells were sensitized with enterotoxin B at a final concentration of $9.8 \mu \mathrm{g} / \mathrm{ml}$ with diazotized benzidine as a coupling reagent. PHA tests were performed in plastic trays (Tomy Seiko, Tokyo) with a $0.5-\mathrm{ml}$ portion of each of serial twofold dilutions of a serum sample and a $0.05-\mathrm{ml}$ portion of a $2.5 \%$ suspension of the sensitized sheep red blood cells. Agglutination was read after 3-hr incubation at room temperature. The reciprocal of the highest dilution of the serum sample giving positive PHA was taken as the PHA titer.

Microslide agar gel diffusion test: The microslide assembly as reported by Crowle (1958) was used. The center well in the template received an enterotoxin B solution at $5 \mu \mathrm{g} / \mathrm{ml}$ (on an antigenicity basis). The four lateral wells received each of serial twofold dilutions of the serum. The slide assemblies were incubated in a moist 
chamber for 3 days at $30 \mathrm{C}$. The reciprocal of the highest dilution of the serum sample giving visible precipitin band was taken as the agar gel diffusion (AGD) titer.

\section{RESULTS}

\section{Immunization with Gradually Increasing Doses}

The development of antitoxin in rabbits immunized by different procedures are shown in Tables I and II; the former shows in PHA and the latter in AGD titers. In rabbits Nos. 1 and 2 immunized by schedule $A$, the antitoxin was first detected

TABLE I

Development of anti-enterotoxin $B\left(\right.$ in PHA titer $\left.\times 10^{-4}\right)$ in rabbits immunized by different procedures

\begin{tabular}{|c|c|c|c|c|c|c|c|c|c|c|c|c|c|}
\hline \multirow{2}{*}{$\begin{array}{c}\text { Rabbit } \\
\text { No. }\end{array}$} & \multirow{2}{*}{ Schedule } & \multicolumn{12}{|c|}{ Period in weeks } \\
\hline & & 1 & 2 & 3 & 4 & 5 & 6 & 7 & 8 & 9 & 10 & 11 & 12 \\
\hline 1 & A & 0.25 & 0.25 & 0.25 & 0.5 & 4 & 32 & 128 & 256 & 256 & 256 & 512 & 512 \\
\hline 2 & $" \prime$ & -* & - & - & 1 & 2 & 4 & 8 & 16 & 64 & 128 & 128 & 256 \\
\hline 3 & B & - & - & 1 & 1 & 2 & 2 & 4 & 16 & 32 & 64 & 256 & 256 \\
\hline 4 & $\mathrm{C}$ & - & 0.25 & 1 & 2 & 8 & 8 & 8 & 16 & 8 & 8 & 16 & 16 \\
\hline 5 & " & 0.1 & 0.5 & 1 & 2 & 4 & 8 & 4 & 8 & 4 & 4 & 8 & 8 \\
\hline 6 & $\mathrm{D}$ & - & 0.1 & 0.1 & 1 & 4 & 8 & 8 & 4 & 8 & 16 & 16 & 16 \\
\hline 7 & " & - & 0.1 & 0.25 & 4 & 16 & 16 & 16 & 8 & 16 & 32 & 32 & 16 \\
\hline 8 & $E$ & 0.5 & 1 & 2 & 8 & 16 & 16 & 32 & 64 & 64 & 256 & 256 & 256 \\
\hline
\end{tabular}

* negative at $1 \times 10^{-3}$ dilution

TABLE II

Development of anti-enterotoxin $B$ (in $A G D$ titer) in rabbits immunized by different procedures

\begin{tabular}{|c|c|c|c|c|c|c|c|c|c|c|c|c|c|}
\hline \multirow{2}{*}{$\begin{array}{l}\text { Rabbit } \\
\text { No. }\end{array}$} & \multirow{2}{*}{ Schedule } & \multicolumn{12}{|c|}{ Period in weeks } \\
\hline & & 1 & 2 & 3 & 4 & 5 & 6 & 7 & 8 & 9 & 10 & 11 & 12 \\
\hline 1 & A & -* & - & 1 & 1 & 4 & 32 & 64 & 128 & 128 & 256 & 256 & 256 \\
\hline 2 & " & \multicolumn{12}{|c|}{ Not determined } \\
\hline 3 & B & - & - & - & - & 2 & 2 & 8 & 16 & 32 & 64 & 64 & 128 \\
\hline 4 & $\mathrm{C}$ & - & - & - & 2 & 2 & 8 & 32 & 32 & 16 & 8 & 16 & 16 \\
\hline 5 & " & $\mathrm{ND}^{* *}$ & ND & ND & ND & 2 & 4 & 4 & 16 & 8 & 4 & 8 & 16 \\
\hline 6 & $\mathrm{D}$ & \multicolumn{12}{|c|}{ Not determined } \\
\hline 7 & " & \multicolumn{12}{|c|}{ Not determined } \\
\hline 8 & $\mathrm{E}$ & - & 4 & 4 & 4 & 16 & 64 & 32 & 64 & 128 & 64 & 128 & 128 \\
\hline
\end{tabular}

* negative with undiluted serum

** Not determined 
by PHA in 1-4 weeks from the first injection. The titers reached $510 \times 10^{4}$ and $260 \times$ $10^{4}$ in 11-12 weeks. In rabbit No. 3 , immunized by schedule $B$, the antitoxin was. first detected in 3 weeks after the first injection. The PHA titer reached $32 \times 10^{4}$ in 9 weeks; after the booster injection given at the 9 th week, it increased to $260 \times 10^{4}$. in 11 weeks.

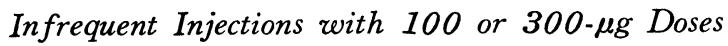

In rabbits Nos. 4 and 5 immunized by schedule $C$ and Nos. 6 and 7 by schedule $\mathrm{D}$, antitoxin was first detected as early as in a week or two; however, the titer did not increase subsequently. The booster injection given at the 7 th or the 8 th week was of little or no effect. The highest titers attained by rabbits of these two groups. ranged $8-32 \times 10^{4}$.

\section{Two Injections with 10- $\mu \mathrm{g}$ Doses}

Rabbit No. 8 was injected primarily with a single dose of $10 \mu \mathrm{g}$ of enterotoxin. with adjuvant and then with $10 \mu \mathrm{g}$ without adjuvant. The antitoxin appeared very early in one week and reached $16 \times 14^{4}$ in 5 weeks. It is noteworthy that the PHA. titer attained after a single primary injection with such a small dose as $10 \mu$ g enterotoxin was significantly higher than those attained with three doses of $100 \mu \mathrm{g}$ or a single dose of $300 \mu \mathrm{g}$. The booster injection with $10 \mu \mathrm{g}$ of enterotoxin given at the 6 th. week was effective and a titer of $260 \times 10^{4}$ was attained at the 10 th weeks.

The AGD titers (Table II) paralleled the PHA titers. The highest AGD titers attained by groups $\mathrm{A}, \mathrm{B}, \mathrm{C}$ and $\mathrm{E}$ were $260,130,16$ and 130 , respectively. AGD titers of group D were not determined. The ratios of PHA to AGD titer were in a range of $10,000-20,000$ at later stages of immunization with the animals of any group.

\section{DISCUSSION}

It is generally accepted that the immunogenicity of protein is dependent upon. various factors including molecular size (Nossal, Ada and Austin, 1964). Staphylococcal. enterotoxin is a protein with relatively a low molecular weight of about 35,000 daltons (Schantz et al., 1965). To obtain anti-enterotoxin, usually a fairly large amount of antigen is injected. Casman and Bennett (1964) injected a rabbit with a total of $8.6 \mathrm{mg}$ of enterotoxin B or $13.5 \mathrm{mg}$ of enterotoxin A; Bergdoll et al. (1964) $30.3 \mathrm{mg}$ of enterotoxin C; Genigeorgis et al. (1971) $3.0 \mathrm{mg}$ of enterotoxin C; Hilker et al. (1968) $1.3 \mathrm{mg}$ of enterotoxin A; Kato et al. (1966) $4.6 \mathrm{mg}$ enterotoxin A; McCoy and Faber (1956) $1.3 \mathrm{mg}$ enterotoxin A; Read et al. (1956) $59.1 \mathrm{mg}$ enterotoxin A; Silverman (1969) $19.5 \mathrm{mg}$ enterotoxin $\mathrm{B}$. Injections into rabbits were made through the sc, ic, im, or iv route or their combinations.

Schedule A in the present study according to Casman et al. (1967) brought about the highest titer; the total amount of antigen injected was also the largest, being 2.14 $\mathrm{mg}$, and the frequency of injection the highest, being 11 times. PHA tests disclosed that the injections with 540 and $1,000 \mu \mathrm{g}$ at the 10 th and 11 th weeks, respectively, were of little or no effect. In fact, schedule B, like that used for immunization with C. perfringens type A enterotoxin by Genigeorgis et al. (1973), attained the same level of antitoxin titer with a total of $208 \mu \mathrm{g}$ of antigen administered in six doses.

From the results of infrequent injections by schedules $\mathrm{C}, \mathrm{D}$ and $\mathrm{E}$ with three 
different doses of the antigen, it seems that an initial injection with a large amount of the antigen results in a low titer. By only two injections each with $10 \mu \mathrm{g}$ of antigen, a titer comparable to those attained by schedule $\mathrm{A}$ or $\mathrm{B}$ resulted. The titer attained by two injections each with $300 \mu \mathrm{g}$ of antigen was only $3 \%$ that attained with 10 and $10 \mu \mathrm{g}$ of antigen. Thus, a primary stimulation of the rabbit with 100 . or $300 \mu \mathrm{g}$ of enterotoxin may have brought about a state of immunological paralysis. like that reported with the mouse injected with $0.5 \mathrm{mg}$ of pneumococcal polysaccharide, which would persist in the body of the recipient for a long time (Felton, 1949). This: was explained to have been due to the relative insusceptibility of pneumococcal polysaccharide to intracellular or extracellular digestion. Protein antigens in general are considered to be more easily digested; however, staphylococcal enterotoxin is known to resist many proteolytic enzymes such as trypsin, pepsin, chymotrypsin, renin and papain (Schantz et al., 1965; Bergdoll, 1966; Chu et al., 1966). It is likely, therefore, that protease-resistant oral toxins such as staphylococcal enterotoxins, C. perfringens type A enterotoxin, and $C$. botulinum progenitor toxins, when injected in relatively a large amount, induce a state similar to immunological paralysis. Injections with gradually increasing doses starting from a very small amount of antigen as. in schedules A and B probably prevented the animal from falling into such a state.

Sakaguchi and Sakaguchi (1973) obtained a highly potent botulinum type E antitoxin $(130 \mathrm{IU} / \mathrm{ml})$ by injecting a rabbit with two doses of $100 \mu \mathrm{g}$ of progenitor toxin. Since the molecular weight of $C$. botulinum type $\mathrm{E}$ progenitor toxin is 350,000 daltons. (Kitamura et al., 1968), 10 times as high as that of staphylococcal enterotoxin, it is. probable that the amount of antigen causing immunological paralysis depends upon. the molecular number rather than the total quantity of the antigen injected primarily. With $C$. perfringens type A enterotoxin with a molecular weight of $34,000-35,000$, daltons (Stark and Duncan, 1972), two injections each with $10 \mu$ grought about a. satisfactorily high antitoxin titer (Sakaguchi et al., 1973). Although only a single rabbit was immunized by Schedule $\mathrm{E}$ in the present investigation and confirmation of the efficiency seems necessary, the same schedule was applied to immunization of rabbits with staphylococcal enterotoxin A and equally satisfactory results were obtained (Shinagawa et al., unpublished data).

From the present results, we would recommend two sc injections each with such a small amount of enterotoxin as $10 \mu \mathrm{g}$ into a rabbit at a proper interval to prepare anti-enterotoxin. This is a very convenient procedure as the laborious work of purification of staphylococcal enterotoxin of each type for the mere purpose of preparing. diagnostic antitoxins can be minimized.

\section{REFERENCES}

Bergdoll, M. S., Borja, C. R. ANd Avena, R. M. (1965): Identification of a new enterotoxin as enterotoxin C. J. Bacteriol., 90, 1481-1485.

CAsman, E. P. AND BENNETT, R. W. (1964): Production of antiserum for staphylococcal enterotoxin. Appl. Microbiol., 12, 363-367.

Casman, E. P., Bennett, R. W., Dorsey, A. E. AND IsSA, J. A. (1967): Identification. of a fourth staphylococcal enterotoxin, enterotoxin D. J. Bacteriol., 94, 1875-1882.

Chu, F. S., Thadhani, K., Schantz, E. J. ANd Bergdoll, M. S. (1966): Purification and characterization of staphylococcal enterotoxin A. Biochemistry, 5, 3281-3289.

Crowle, A. J. (1958): A simplified micro double-diffusion agar precipitin technique. J. Lab. 
Clin. Med., 52, 784-787.

FELTON, L. D. (1949): The significance of antigen in animal tissues. J. Immunol., 61, 107117.

Genigeorgis, C., Foda, M. S., Mantis, A. And SAdleR, W. W. (1971): Effect of sodium chloride and $\mathrm{pH}$ on enterotoxin $\mathrm{C}$ production. Appl. Microbiol., 21, 862-866.

Genigeorgis, C., SAKaguchi, G. AND Rieman, H. (1973): Assay methods for Clostridium perfringens type A enterotoxin. Appl. Microbiol., 26, 111-115.

Hall, H, E., ANGelotti, R. AND Lewis, K. H. (1965): Detection of the staphylococcal enterotoxins in food. Health Lab. Sci., 2, 179-191.

Hilker, J. S., Heilman, W. R., TAN, P. L., Denny, C. B. And Bohrer, C. W. (1968): Heat inactivation of enterotoxin A from Staphylococcus aureus in veronal buffer. Appl. Microbiol., 16, 308-310.

Kato, E., Khan, L., Kujovich, L. And Bergdoll, M. S. (1966): Production of enterotoxin A. Appl. Microbiol., 14, 966-972.

Kitamura, M., SAKaguchi, S. AND SAKaguchi, G. (1968): Purification and some properties of Clostridium botulinum type $\mathrm{E}$ toxin. Biochim. Biophys. Acta, 168, 207-217.

MCCOY, D. W. AND FABER, J. E. (1966): Influence of food microorganisms on staphylococcal growth and enterotoxin production in meat. Appl. Microbiol., 14, 372-377.

Nossal, G. J. V., ADA, G. L. AND Austin, C. M. (1964): Antigens in immunity. II. Immunogenic properties of flagella, polymerized flagellin and flagellin in the primary response. Australian J. Exp. Biol. Med. Sci., 42, 283-294.

Read, R. B., JR., Pritchard, W. L., Bradshaw, J. AND Black, L. A. (1965): In vitro assay of staphylococcal enterotoxins A and B from milk. J. Dairy Sci., 48. 411-421.

SAKAGUCHI, G. AND SAKAGUCHI, S. (1973): Development of antibody to each component of Clostridium botulinum type E progenitor toxin. Japan. J. Med. Sci. Biol., 26, 187-195.

Sakaguchi, G., Uemura, T. AND RiemanN, H. P. (1973): Simplified method for purffication of Clostridium perfringens type A enterotoxin. Appl. Microbiol., 26, 762-767.

Schantz, E. J., Roessler, W. G., Wagman, J., Spero, L., Dunnery, D. A. And BergDOLL, M. S. (1965): Purification of staphylococcal enterotoxin B. Biochemistry, 4, 10111016.

SILVERMAN, S. J. (1963): Serological assay of culture filtrates for Staphylococcus enterotoxin. J. Bacteriol., 85, 955-956.

STARK, R. L. AND DUNCAN, C. L. (1972): Purification and biochemical properties of Clostridium perfringens type A enterotoxin. Infect. Immunity, 6, 662-673.

Surgalla, M. J., Bergdoll, M. S. AND DACK, G. M. (1952): Use of antigen-antibody reactions in agar to follow the progress of fractionation of antigenic mixtures; application to purification of staphylococcal enterotoxin. J. Immunol., 69, 357-365. 